\title{
A Comparison of the Properties of Two Forms of Tyrosinase from Neurospora crassa
}

\author{
ALFRED S. SUSSMAN 1,2 \\ From the Department of Botany, University of Michigan, Ann Arbor, Michrgan \\ Received July 13, 1961
}

\begin{abstract}
The differences between a thermostable ( $\mathrm{T}^{\mathrm{s}}$ ) and thermolahile ( $\mathrm{T}^{\mathrm{L}}$ ) form of tyrosınase from Neurospora crassa have been studied by means of a spectrophotometrie technique using ascorbate or ferrocyanide. No significant differences in substrate specificity have been found in a survey of over 30 substanees which included mono-, di-, tri-, and conjugated phenols. Catechol was found to be a substrate, in contrast to previous findings. Michaelis-Menten constants for the two forms of enzyme acting on L-tyrosine and $\boldsymbol{t}$ - and D-hydroxyphenylalanine (Dopa) also were found to be similar, as were the $\mathrm{pH}$ optima on L-Dopa and phenyl-4-catechol, and the response to several inhibitors. On the other hand, the activity of the thermolabile enzyme was lost more rapidly than that of the thermostable one after incubation for $515 \mathrm{~min}$. in high conecntrations of urea and formamide. These data are interpreted as support for the conclusion that the two forms of the enzyme differ mainly in their secondary and tertiary structure and not in their active centers.
\end{abstract}

\section{INTRODUCTION}

The template theory of gene action requires that the specificity inherent in a gene be reflected in an ordered arrangement of the amino acids in one protein, and in no other. These products of the gene, through their enzymic activities, determine the phenotype of the organism. Although this model is oversimplified, it has served as a useful framework for experimentation directed toward the understanding of the nature of the gene. Thus, one of the predictions that follows from the template theory is that different alleles should produce qualitative variations in gene products.

This question has been studied in detail in Neurospora wherein several forms of tyrosinase have been shown to exist (6). These were first distinguished on the basis of their heat resistance and, more recently, have

${ }^{1}$ This work was performed during the author's tenure of a National Science Foundation Senior Postdoctoral Fellowship at the California Institute of Technology.

'Paper No. 1126 from the Department of Botany, University of Michigan. been shown to differ in their electrophoretic properties $(8,9)$. On the other hand, in these earlier experiments with relatively impure preparations, these enzymes appeared to have similar substrate specificity (6), Michaelis-Menten constants, and $\mathrm{pH}$ optima (7). Therefore, on the basis of these experiments it was suggested that the different forms of tyrosinase were alike functionally but differed in structure. Among the three genetic loci which have been identified as influencing the production of tyrosinase, ty-1 and ty-2 regulate the production of the inducer, or of the repressor, whercas T-locus appears to determine the structure of this enzyme (8). The present work was initiated in order to explore the functional aspects of tyrosinase activity, using purificd enzymes, so that a detailed comparison between the stable $\left(\mathrm{T}^{\mathrm{S}}\right)$ and labile $\left(\mathrm{T}^{\mathrm{L}}\right)$ forms could be made.

\section{METHODS}

\section{Crlture Techniqles}

Strains of Neurospora crassa which wele used include 69-1113a $\left(\mathrm{T}^{\mathrm{s}}\right), 65-811 \mathrm{~A}\left(\mathrm{~T}^{\mathrm{t}}\right)$, and $913_{\mathrm{s} 3} \mathrm{~A}$ 


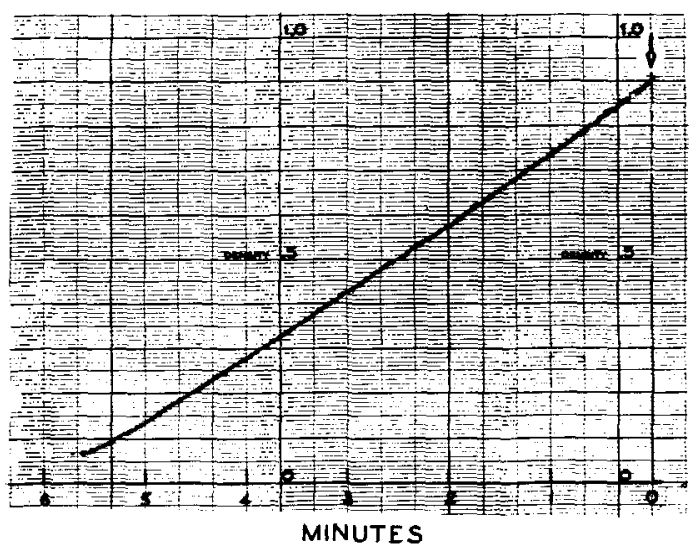

Fig. 1. Oxidation of $5.7 \times 10^{-5} M$ L-Dopa by tyrosinase from Neurospora $\left(\mathrm{T}^{\mathrm{S}}\right)$ as determined by the ascorbate assay. The abscissa of the recorder paper represents optical density and the arrow indicates the time of addition of the substrate.

(ty-1). Crude enzyme preparations were obtained by growing the organism on Vogel's medium $N$ (21) containing only $6 \times 10^{-5} M$ sulfate. Cultures were grown for 4 days at $25^{\circ} \mathrm{C}$. in $125-\mathrm{ml}$. Erlenmeyer flasks containing $20 \mathrm{ml}$. medium.

Large quantities of mycelium were obtained through the use of aerated submerged cultures in $10-1$. bottles containing $8 \mathrm{l}$. of the medium described above. The organism was grown in the dark at $25^{\circ} \mathrm{C}$. for 3 days, upon which the mycelium was transferred under sterile conditions to another bottle containing 81 . of $0.05 M$ phosphate buffer at $\mathrm{pH} 5.5$ in which it was maintained for $2-3$ days before harvest.

Crude extracts were prepared by grinding mycelium in $0.1 M$ phosphate buffer at $\mathrm{pH} 6.0$ as described previously (6).

\section{Preparation and Assay of Enzymes}

Purification was carried out through the stages described by these authors followed by passage through a Celite column. ${ }^{3}$ By this means, the enzyme from $\mathrm{T}^{\mathrm{L}}$ was brought to a specific activity of 157,500 units/mg. protein, which represents about a 400 -fold increase in purity over the starting material. A unit of enzyme is defined as the increase in absorbancy with $2 \times 10^{-2} M$ DL-dihydroxyphenylalanine (Dopa) as substrate in $0.1 \mathrm{M}$ phosphate buffer at $\mathrm{pH} 6.0$, at $25^{\circ} \mathrm{C}$. for $5 \mathrm{~min}$, using a Klett colorimeter with a blue filter (Klett 42). The purified enzyme from $T^{\mathrm{s}}$ which was used was a gift from Dr. Marguerite Fling and had a specific activity of 160,000 . Recently, the enzyme

${ }^{3}$ N. H. Horowitz and M. Fling, personal communieation. from $\mathrm{T}^{\mathrm{s}}$ has been crystallized ${ }^{3}$ and shown to have a specific activity of 180,000 in this form. On this basis, the purified enzyme from $\mathrm{T}^{\mathrm{L}}$ used was $80 \%$ pure and that from $\mathrm{T}^{\mathrm{s}}$ was about $89 \%$ pure.

Comparisons between the manometric and colorimetric methods of determining the activity of tyrosinase from Neurospora have been made (6) thereby permitting the conversion of the specific activities given above into units which are equivalent to the amount of enzyme required to cause the uptake of $10 \mathrm{cu} . \mathrm{mm}$. oxygen $/ \mathrm{min}$. (5). When expressed in these terms, each milliliter of the purified preparation from $\mathrm{T}^{\mathrm{L}}$ had 1050 units of activity and that from $\mathrm{T}^{\mathrm{s}}$ had 1155 units.

Unless otherwise stated, the following experiments were performed with the purified enzyme preparations.

Tyrosinase activity was determined by a method which is an elaboration of one first reported previously $(2,20,23)$. This method measures the decrease in optical density of ascorbate at $265 \mathrm{~m} \mu$ as a result of the oxidation of a substrate for the enzyme. Unless otherwise specified, the concentration of the reactants used in a total volume of 3 ml. was $7 \times 10^{-6} M$ ascorbate, $1.5 \times 10^{-5} M$ ethylenediaminetetraacetic acid (free acid), and $0.1 \mathrm{ml}$. enzyme to which $0.1 \mathrm{ml}$. of the substrate was added at zero time. All reagents were made up in $0.1 \mathrm{M}$ phosphate buffer at $\mathrm{pH} 6.0$, and the ascorbic acid and phenolic substrates were prepared immediately before use. The change in optical density was followed with a Cary recording spectrophotometer (model 11MS) running at a roller speed of $1 \mathrm{in./}$ min., so that permanent records were available from which calculations could be made. Under these conditions, linearity was maintained with most. substrates for at least $2 \mathrm{~min}$., as can be seen in the sample curve in Fig. 1. Therefore, the decrease in optical density over the linear portion of the curve was computed, and the average rate per minute, corrected for the autoxidation of ascorbate, was used as the measure of tyrosinase activity. However, some reaction-inactivation was apparent almost immediately when catechol was used so that the values for its rate of oxidation are subject to considcrable error. In the case of tyrosine, calculations were made from the linear part of the curve, after the lag period in its oxidation was over (Fig. 2).

The validity of this assay system for use with Nearospora was checked in several ways. Thus, the use of ascorbic acid, without substrates of tyrosinase, but with enzyme extracts, disclosed that there was no ascorbic acid oxidase present. That the concentration of ascorbic acid used was not critical in this system is revealed by the data in Table $I$ in which no change in rate is shown. These data are in accord with the conclusions of others 
(11, 19) that ascorbate does not affect the rate of oxidation of catechol by polyphenol oxidase. That the rate of oxidation by tyrosinase in this system is directly proportional to enzyme concentration was also demonstrated so that this assay appears to be valid for use with diphenols.

On the other hand, increasing concentrations of ascorbate extend the lag in tyrosine oxidation, whether purified or crude enzyme preparations were used. There are additional reasons for suspecting the validity of the rates obtained with monophenols, a detailed discussion of which will be deferred until later.

A test of the specificity of the assay was performed by using extracts of strains of Neurospora crassa which were devoid of tyrosinase activity. Extracts of $t y-1$ and of an unnumbered strain which I had isolated induced no oxidation of ascorbate above the background of autoxidation in the presence of $3.3 \times 10^{-5} M$ L-Dopa, thereby strengthening the assumption that tyrosinase activity was being measured by this technique.

Ferrocyanide was used as a reductant in the spectrophotometric assay of tyrosinase by substituting $0.02 M \mathrm{~K}_{4} \mathrm{Fe}(\mathrm{CN})_{6} .3 \mathrm{H}_{2} \mathrm{O}$ for the ascorbate in the system described above. The rate of increase in optical density at $420 \mathrm{~m} \mu$ upon the oxidation of the ferrocyanide was used as the index of activity. No effect of ferrocyanide concentration upon the rate of oxidation of $6.7 \times 10^{-5}$ $M$ L-Dopa was detectable between 0.0067 and 0.033 $\boldsymbol{M}$. Furthermore, ferrocyanide, in the presence of substrate, was oxidized in direct proportion to

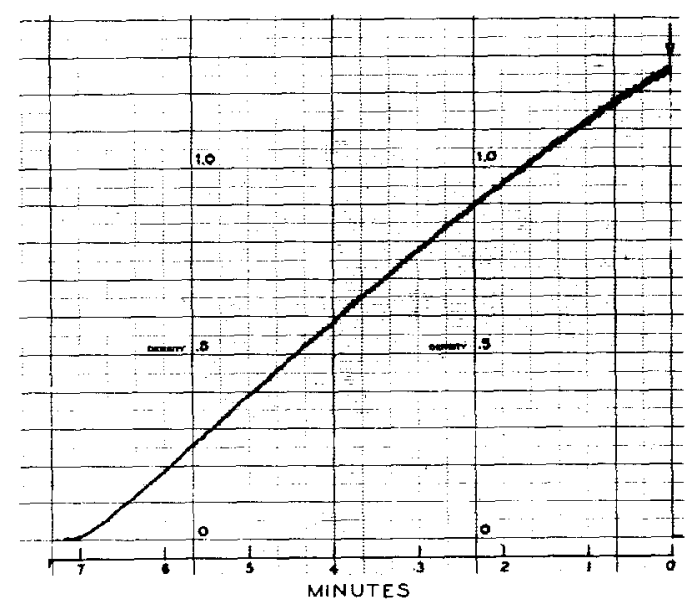

FIg. 2. Oxidation of $7.1 \times 10^{-5} M$ DL-tyrosine by tyrosinase from Neurospora $\left(\mathrm{T}^{\mathrm{S}}\right)$ as determined by the ascorbate assay. Note the "lag" period which extends over the first $4 \mathrm{~min}$. The abscissa represents optical density and the arrow indicates the time of addition of the substrate.
TABI.E I

Effect of Varying the Concentration of Ascorbate in the Assay of

Nevrospora Tyrosinase

A crude enzyme preparation was used.

\begin{tabular}{lc}
\hline Ascorbic acid concentration & $\Delta$ opt. dens. $\times 10^{3} / \mathrm{min}$. \\
\hline Substrate: & \\
$3.3 \times 10^{-5} M$ DL-Dopa & 114 \\
$3.5 \times 10^{-6}$ & 122 \\
$7.0 \times 10^{-6}$ & 117 \\
$1.0 \times 10^{-5}$ & 114 \\
$1.4 \times 10^{-5}$ & 125 \\
$2.1 \times 10^{-5}$ & \\
Substrate $:$ & \\
$6.7 \times 10^{-7} M$ L-tyrosine & 17 \\
$6.7 \times 10^{-6}$ & 18 \\
$9.0 \times 10^{-6}$ & 17 \\
$1.1 \times 10^{-5}$ & \\
\hline
\end{tabular}

enzyme concentration so that the method proved to be feasible. Several advantages accrue to the use of ferrocyanide instead of ascorbate, including:

1. The assay starts from zero optical density so that background "chatter" in the instrument is minimized.

2. Ferrocyanide is not as sensitive as ascorbate to changes in $\mathrm{pH}$, especially in the acid range, because its oxidation-reduction potential is less affected.

3. Ferrocyanide is stable in solution and can be stored for repeated use.

4. Tyrosinase activity in the presence of substrates, as well as inhibitors, which absorb strongly in the region of $265 \mathrm{~m} \mu$ can be assayed, whereas in the ascorbate system it is difficult to do so.

On the other hand, the sensitivity of the ferrocyanide technique is less than half that of the one using ascorbate, on the basis of comparisons using the same concentration of substrate in both assays.

Specific activities during enzyme purification were computed on the basis of protein determinations which were performed by the method of Lowry et al. (16).

\section{RESULTS}

Michaclis constants were derived as a means of comparing the enzymes from $\mathrm{T}^{\mathrm{s}}$ and $\mathrm{T}^{\mathbf{L}}$. This was accomplished for $\mathrm{L}$-tyrosine, L-Dopa, and D-Dopa, with both crude and purified enzymes, with the results shown in Table II and Fig. 3. In general, there appears to be a close similarity between the $K_{\mathrm{s}}$ values of the two forms of tyrosinase. 


\section{TABLE II}

Michaelis Constants $\left(K_{S}\right)$ for Stable ( ${ }^{\prime s}$ ) aNd Labile (TL) Forms of Tyrostnase FROM NEUROSPORA

Data calculated by least-squares analysis of at least eight points. Paired values were obtained from experiments performed on the same day.

\begin{tabular}{l|c|c|c}
\hline \multicolumn{1}{c|}{ Substrate } & $\begin{array}{c}\text { Purity of } \\
\text { enzyme }\end{array}$ & \multicolumn{2}{|c}{$K_{S}$ of tyrosinase from: } \\
\cline { 2 - 3 } & & $T^{\mathbb{S}}$ & $T^{\mathrm{L}}$ \\
\hline L-Tyrosine & Crude & $1.8 \times 10^{-4}$ & - \\
& Crude & $1.9 \times 10^{-4}$ & - \\
& & $5.3 \times 10^{-4}$ & - \\
L-Dopa & Purified & $5.3 \times 10^{-5}$ & $1.0 \times 10^{-4}$ \\
L-Dopa & Purified & $1.9 \times 10^{-4}$ & $4.0 \times 10^{-4}$ \\
& & $2.6 \times 10^{-4} ;$ & $5.3 \times 10^{-4}$ \\
D-Dopa & Purified & $1.4 \times 10^{-4}$ & $1.2 \times 10^{-4}$ \\
& & $1.5 \times 10^{-4} ;$ & $2.0 \times 10^{-4} ;$ \\
\hline
\end{tabular}

Their substrate specificity was also studied, and the results are summarized in Table III. Once again there is a close parallel between the activities of the two enzymes. These data also extend the range of substrates utilized by Neurospora tyrosinase to include catechol, phenyl-4-catechol, caffeic acid, chlorogenic acid, 4-hydroxyphenol acetic acid, pyrogallol, 3,4-dihydroxybenzoic acid, and 3,4-dihydroxybenzaldehyde, as well as the ones reported previously $(6$, $10)$. It is noteworthy that phenyl-4-catechol is the best substrate of those tried, and catechol is rapidly oxidized by the enzyme, contrary to previous reports $(10,15)$.

Because measurement of tyrosinase activity on catechol by means of the ascorbate assay was rendered inaccurate by the high absorbance of the substrate at $265 \mathrm{~m} \mu$, the ferrocyanide assay was applied. In addition, the color of oxidized catechol was followed directly at $460 \mathrm{~m} \mu$ in order to determine enzyme activity by another means. Both methods of assay, according to the data in Table IV, establish that catechol is a substrate for Neurospora tyrosinase. However, a comparison of the curves in Fig. 4 with those in Figs. 1 and 2 will reveal that reaction-inactivation of the enzyme is ex- tremely rapid in the presence of catechol as compared with that when other substrates are used. In fact, the oxidation of this substrate might well be overlooked in assays like the manometric ones in which changes within the first minute of mixing are difficult to measure.

The $\mathrm{pH}$ optima of the two forms of tyrosinase were determined for L-Dopa and phenyl-4-catechol. As the curves in Figs. 5 and 6 show, the optimum is broad and extends from $\mathrm{pH} 5$ through 8 for L-Dopa and from $\mathrm{pH} 5$ through 9 for phenyl-4-catechol. Some difficulties in measurement were experienced above $\mathrm{pH} 9$ due to the toxicity of borate and the high rate of autoxidation of the phenolic substrates and ascorbate. In addition, the enzyme has been found to be unstable above $\mathrm{pH} 10$.

Another difficulty associated with the use of ascorbate is the increase in its oxidationreduction potential as the $\mathrm{pH}$ is lowered (1). Therefore, the measurement of tyrosinase activity at $\mathrm{pH} 4.0$ and below might be handicapped by the decreased oxidizability of ascorbate. This was checked by the use of the ferrocyanide method, as a result of which the data in Table $V$ were obtained. These results substantiate those presented in Fig. 5, placing the $\mathrm{pH}$ minimum at about 3.5 for L-Dopa. However, it should be noted that the enzyme may be irreversibly inactivated below pH 4.5 so

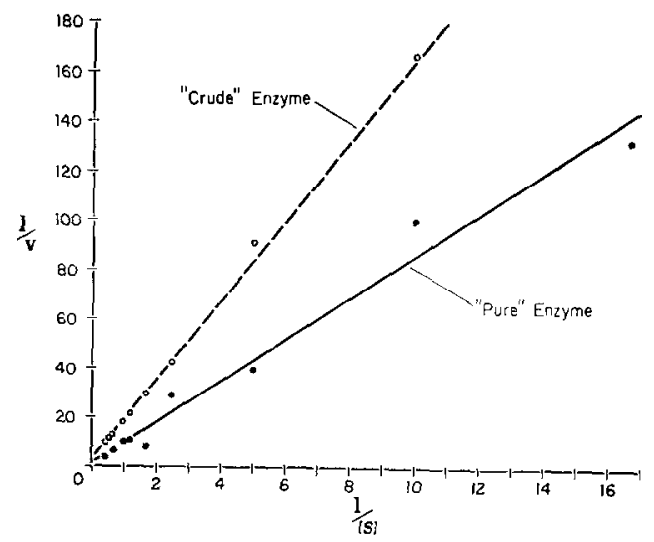

FIG. 3. Lineweaver-Burk plot of activity of tyrosinase $\left(\mathrm{T}^{\mathrm{s}}\right.$ ) from Neurospora, using "purified" and crude preparations. Substrate used was L-Dopa. Units used: $V=\triangle$ optical density $/ \mathrm{min}$; $S=$ molarity of substrate. 
TABLE III

Velocity of Oxidation of Various Phenols in the Presence of the stable (Ts) AND LaBILE (TL) FORMS OF 'TYROSINASE

\begin{tabular}{|c|c|c|c|c|c|}
\hline \multirow{2}{*}{ Substrate } & \multirow{2}{*}{ Concentration } & \multicolumn{2}{|c|}{ Velncity ${ }^{a} \times 10^{3}$} & \multicolumn{2}{|c|}{ Per cent activity on L-Dopa } \\
\hline & & $\mathrm{T}^{5}$ & $\mathrm{~T}^{\mathbf{L}}$ & $T^{s}$ & $T^{L}$ \\
\hline & $M$ & & & & \\
\hline $\begin{array}{l}\text { L-Dihydroxyphenylal- } \\
\text { anine (L-Dopa) }\end{array}$ & $3.6 \times 10^{-5}$ & 72.5 & 68.0 & 100 & 100 \\
\hline \multirow[t]{3}{*}{ Catechol } & $0.7 \times 10^{-5}$ & 24.5 & 22.0 & 33.8 & 32.4 \\
\hline & $3.6 \times 10^{-5}$ & 77.5 & 80.0 & 107 & 117 \\
\hline & $2.1 \times 10^{-3}$ & 0 & 0 & 0 & 0 \\
\hline Resorcinol & $3.6 \times 10^{-4}$ & 1.0 & 2.0 & 1.4 & 2.9 \\
\hline Orcinol & $3.6 \times 10^{-3}$ & 0.4 & 2.2 & 0.5 & 3.2 \\
\hline \multirow[t]{3}{*}{ Hydroquinone } & $3.6 \times 10^{-5}$ & 2.0 & 2.0 & 2.8 & 2.9 \\
\hline & $7.1 \times 10^{-5}$ & 2.5 & 1.5 & 3.4 & 2.2 \\
\hline & $3.6 \times 10^{-4}$ & 5.6 & 2.1 & 7.7 & 3.1 \\
\hline 2-Methylhydroquinone & $3.6 \times 10^{-5}$ & 0 & 0.6 & 0 & 0.9 \\
\hline \multirow[t]{2}{*}{ Phenyl-4-catechol } & $3.6 \times 10^{-5}$ & 303.5 & $\theta$ & 418 & - \\
\hline & $0.7 \times 10^{-5}$ & 86.0 & 83.0 & 118.6 & 122.0 \\
\hline $\begin{array}{l}3,4 \text {-Dihydrocinnamic } \\
\text { acid (caffeic acid) }\end{array}$ & $7.1 \times 10^{-5}$ & 61.8 & 60.5 & 85.2 & 88.9 \\
\hline ChIorogenic acid & $7.1 \times 10^{-3}$ & 63.2 & 67.2 & 87.2 & 98.6 \\
\hline$p$-Phenylenediamine & $3.6 \times 10^{-4}$ & 2.0 & 2.0 & 2.8 & 2.9 \\
\hline L-Tyrosine & $3.6 \times 10^{-5}$ & 43.1 & 38.4 & 59.5 & 56.4 \\
\hline I) $\mathrm{I}_{-}-m$-Tyrosine & $7.1 \times 10^{-5}$ & 0.6 & 4.0 & 0.9 & 5.9 \\
\hline DL-o-Tyrosine & $7.1 \times 10^{-5}$ & 1.0 & 3.0 & 1.4 & 4.4 \\
\hline 3-Indotyrosine & $3.6 \times 10^{-5}$ & 3.9 & 4.4 & 5.4 & 6.5 \\
\hline 3,5-Diiodotyrosine & $3.6 \times 10^{-5}$ & 3.0 & 6.0 & 4.1 & 8.8 \\
\hline \multirow[t]{2}{*}{3 -Nitrotyrosine } & $7.1 \times 10^{-5}$ & 1.3 & 5.2 & 1.8 & 7.6 \\
\hline & $3.6 \times 10^{-5}$ & 0.7 & 1.6 & 0.9 & 2.3 \\
\hline \multirow[t]{2}{*}{ Phenol } & $1 \times 10^{-4}$ & 16.3 & 12.6 & 22.5 & 18.5 \\
\hline & $4.2 \times 10^{-4}$ & 41.8 & 36.2 & 57.7 & 53.2 \\
\hline \multirow{2}{*}{$\begin{array}{l}\text { 4-Hydroxyphenol } \\
\text { acetic acid }\end{array}$} & $7.1 \times 10^{-5}$ & 6.8 & 9.3 & 9.4 & 13.7 \\
\hline & $3.6 \times 10^{-4}$ & 35.1 & 30.6 & 48.4 & 45.0 \\
\hline $2,4,6$-Trichlorophenol & $7.1 \times 10^{-5}$ & 1.9 & 3.7 & 2.6 & 5.8 \\
\hline 2-Aminophenol & $3.6 \times 10^{-5}$ & 5.4 & 4.4 & 7.5 & 6.5 \\
\hline$\alpha$-Naphthol & $7.1 \times 10^{-5}$ & 1.2 & 0.8 & 1.7 & 1.2 \\
\hline \multirow[t]{2}{*}{ Pyrogallol } & $7.1 \times 10^{-5}$ & 9.2 & 6.0 & 12.7 & 8.8 \\
\hline & $3.6 \times 10^{-4}$ & 54,9 & 42.1 & 75.7 & 61.9 \\
\hline Gallic acid & $1.8 \times 10^{-4}$ & 0.7 & 1.1 & 1.0 & 1.6 \\
\hline Shikimie acid & $3.2 \times 10^{-5}$ & 0 & 2.9 & 0 & 4.3 \\
\hline Quinic acid & $3.6 \times 10^{-3}$ & 0 & 0 & 0 & 0 \\
\hline Phloroglucinol & $3.6 \times 10^{-5}$ & 0.6 & 1.4 & 0.8 & 2.1 \\
\hline \multirow[t]{2}{*}{ 3-Hydroxybenzoic acid } & $7.1 \times 10^{-5}$ & 1.0 & 1.5 & 1.4 & 2.2 \\
\hline & $3.6 \times 10^{-4}$ & 1.1 & 1.8 & $1 . \overline{0}$ & 2.6 \\
\hline 4-Hydroxybenzoic acid & $7.1 \times 10^{-5}$ & 3.3 & 0 & 4.6 & 0 \\
\hline 3,4-Dihydroxybenzoic & $7.1 \times 10^{-5}$ & 11.7 & 11.1 & 16.1 & 16.3 \\
\hline acid & $3.6 \times 10^{-4}$ & 44.2 & 36.3 & 61.2 & 53.4 \\
\hline 2,3-Dihydroxybenzoic: & $7.1 \times 10^{-5}$ & 1.7 & 2.3 & 2.3 & 3.4 \\
\hline acid & $3.6 \times 10^{-4}$ & 1.1 & 1.3 & 1.5 & 1.9 \\
\hline 3,4-Dihydroxybenzal- & $3.6 \times 10^{-5}$ & 9.3 & 7.6 & 12.8 & 11.2 \\
\hline dehyde & $7.1 \times 10^{-5}$ & 11.7 & 14.1 & 16.1 & 20.7 \\
\hline 4-Hydroxybenzaldehyde & $7.1 \times 10^{-5}$ & 0.3 & 0.9 & 0.4 & 1.3 \\
\hline
\end{tabular}

a Velocity calculated as $\Delta$ optical density of ascorbate $/ \mathrm{min}$. with $0.1 \mathrm{ml}$. enzyme, corrected for differences in activity of the enzyme by using the rates for $3.6 \times 10^{-5} M \mathrm{~L}$-Dopa as standards. The autoxidation of substrates is subtracted in the values given above. 
that activities measured below this point are difficult to interpret. ${ }^{3}$

The effect of metal-binding agents and some other compounds is shown in Table VI. As expected, phenylthiourea, sodium diethyldithiocarbamate, cysteine, and sodium azide are extrcmely inhibitory, whercas

\section{TABLE IV}

Oxidation of Catechol by NeURospora

Tyrosinase Measured by Means of the Ferrocyanide Assay and Directly by the Change in Optical Density at $460 \mathrm{~m}_{\mu}$

A purified enzyme from $\mathrm{T}^{\mathrm{s}}$ was used throughout.

\begin{tabular}{ccc}
\hline Catechol concentration & Assay method & $\begin{array}{c}\Delta \text { opt.density } \\
\times 10^{3}\end{array}$ \\
\hline$M$ & & \\
$3.3 \times 10^{-5}$ & "Direct" & 10.0 \\
$6.7 \times 10^{-5}$ & & 19.0 \\
$1.7 \times 10^{-4}$ & & 43.0 \\
$3.3 \times 10^{-4}$ & & 47.5 \\
$1.0 \times 10^{-3}$ & & 24.5 \\
$1.7 \times 10^{-3}$ & & 14.5 \\
& & \\
$6.6 \times 10^{-5}$ & Ferrocyanide & 46.0 \\
$1.7 \times 10^{-4}$ & & 81.5 \\
$3.3 \times 10^{-4}$ & & 82.0 \\
$6.7 \times 10^{-4}$ & & 85.5 \\
$1.0 \times 10^{-3}$ & & 91.5 \\
$1.3 \times 10^{-3}$ & & 44.0 \\
$1.7 \times 10^{-3}$ & & 19.0 \\
$1.0 \times 10^{-2}$ & & 20.0 \\
\hline
\end{tabular}

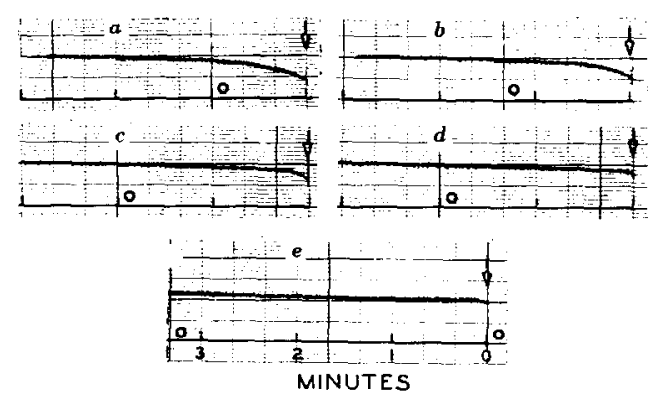

Fig. 4. Oxidation of catechol by tyrosinase from Neurospora $\left(\mathrm{T}^{\mathrm{s}}\right)$ as determined in the ferrocyanide assay. Scale and axes as in Figs. 1 and 2. Concentrations of catechol used are as follows: curve $a$, $1.8 \times 10^{-4} \mathrm{M}$; curve $b, 3.6 \times 10^{-4} \mathrm{M}$; curve $c$, $7.1 \times 10^{-4} \mathrm{M}$; curve $d, 1.4 \times 10^{-3} \mathrm{M}$; curve $e$, $1.8 \times 10^{-3} \mathrm{M}$.

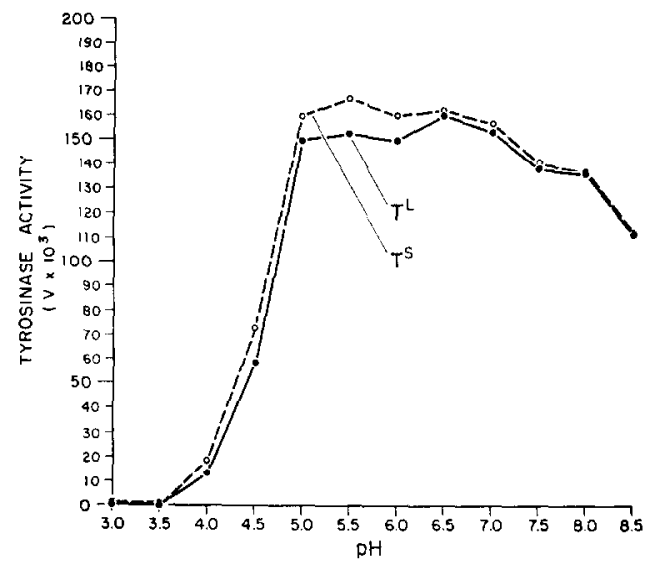

FIG. 5. Effect of $\mathrm{pH}$ upon the activity of tyrosinase from Neurospora on L-Dopa. Closed circles represent the values obtained for the thermolabile enzyme $\left(T^{\mathrm{L}}\right)$ and open circles those from the thermostable enzyme $\left(\mathrm{T}^{\mathrm{B}}\right)$. The buffers were used at a concentration of $0.1 \mathrm{M}$ and included the following: citrate-phosphate ( $\mathrm{pH} 3.0$ through 7.0), phosphate $(\mathrm{pH} 7.5$ and 8.0 ), and Tris $(\mathrm{pH} 8.0$ and 8.5).

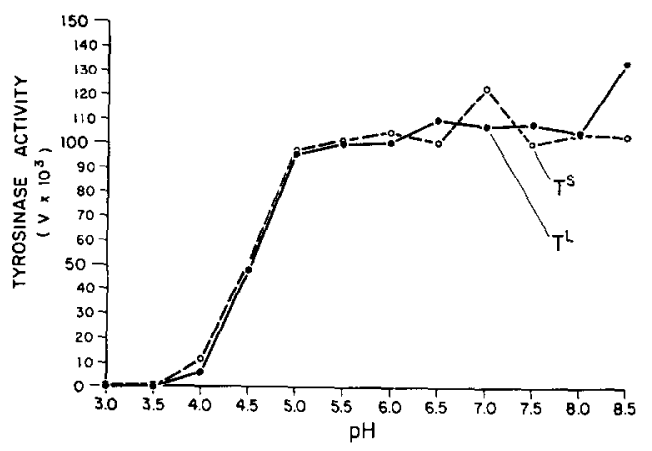

Fia. 6. Effect of pH upon the activity of tyrosinase from Neurospora on phenyl-4-catechol. Closed circles represent the values obtained for the thermolabile enzyme $\left(\mathrm{T}^{\mathrm{L}}\right)$ and open circles those from the thermostable enzyme $\left(T^{\mathrm{s}}\right)$. Buffers used as in Fig. 5.

benzoic acid is somewhat less so. On the other hand, quinic and shikimic acids, intermediates in aromatic biosynthesis, do not inhibit the enzyme, even in relatively high concentrations. No difference in the action of these substances on the two forms of the enzyme was detectable.

\section{Treatment with Unfolding Agents}

Substances which induce the unfolding of proteins $(22)$ were added to the enzyme and 
incubated for up to $15 \mathrm{~min}$. before the activity was measured. The appropriate amount of urea was added to $0.1 \mathrm{ml}$. of the enzyme and incubated. At the end of this time the volume was made up to $3 \mathrm{ml}$, and

\section{TABLE $V$}

Effect of $\mathrm{PH}$ on the Stable (TS) and Labile (TL) Forms of Tyrosinase in Necrospora, as Measured by The Ferrocyanide TechNique

Concentration of $\mathrm{L}_{-}$- Dopa used as substrate was $7.2 \times 10^{-4} M$. Data corrected for autoxidation.

\begin{tabular}{|c|c|c|c|c|c|}
\hline \multirow{2}{*}{$\mathrm{pH}$} & \multirow{2}{*}{ Buffer } & \multicolumn{2}{|c|}{$\Delta$ opt. dens. $\times$} & \multicolumn{2}{|c|}{$\int_{\text {rate }}^{\text {Per cent control }}$} \\
\hline & & $T^{s}$ & $T^{L}$ & $T^{S}$ & $\mathrm{~T}^{\mathrm{L}}$ \\
\hline 6.0 & Phosphate & 186 & 160 & 100 & 100 \\
\hline 3.0 & Citrate & 0 & 0 & 0 & 0 \\
\hline 3.5 & Citrate & 4 & 7 & 2 & 4 \\
\hline 4.0 & Citrate & 39 & 25 & 21 & 16 \\
\hline 4.5 & Citrate & 121 & 110 & 65 & 69 \\
\hline 5.0 & Citrate & 194 & 180 & 104 & 112 \\
\hline 9.0 & Tris & 69 & 57 & 37 & 36 \\
\hline
\end{tabular}

\section{TABLE VI}

Effect of Metal-Binding Agents and Other Compolinds lpon the Stable (Ts) and Labile (TL) Forms of Tyrosinase FROM NEUROSPORA

Concentration of L-Dopa used as substrate was $3.6 \times 10^{-5} \mathrm{M}$.

\begin{tabular}{|c|c|c|c|c|c|}
\hline \multirow{2}{*}{ Substance } & \multirow{2}{*}{ Concentration } & \multicolumn{2}{|c|}{$\Delta \underset{\times 10^{3}}{ }$} & \multicolumn{2}{|c|}{$\begin{array}{l}\text { Per cent } \\
\text { control rate }\end{array}$} \\
\hline & & $T^{S}$ & $\mathrm{~T}^{\mathrm{L}}$ & $T^{S}$ & $\mathrm{~T}^{\mathrm{T}}$ \\
\hline & $M$ & & & & \\
\hline Control & - & 148 & 142 & 100 & 100 \\
\hline \multirow{2}{*}{ Phenylthiourea } & $2.2 \times 10^{-5}$ & 52 & - & 35 & - \\
\hline & $1.1 \times 10^{-4}$ & 28 & 24 & 18 & 17 \\
\hline Sodium azide & $7.1 \times 10^{-5}$ & 10 & 11 & 7 & 8 \\
\hline \multirow[t]{2}{*}{ Cysteine } & $3.6 \times 10^{-5}$ & 75 & 66 & 50 & 47 \\
\hline & $1.8 \times 10^{-4}$ & 29 & 21 & 19 & 15 \\
\hline Benzuic ateid & $7.1 \times 10^{-4}$ & 49 & 48 & 32 & 34 \\
\hline $\begin{array}{l}\text { Sodium diethyl- } \\
\text { dithiocarba- } \\
\text { mate }\end{array}$ & $7.1 \times 10^{-5}$ & 14 & 9 & 10 & 7 \\
\hline Control $^{a}$ & - & 155 & 115 & 100 & 100 \\
\hline Quinic acid ${ }^{u}$ & $3.6 \times 10^{-3}$ & 151 & 117 & 97 & 101 \\
\hline Shikimic acid ${ }^{a}$ & $3.6 \times 10^{-3}$ & 142 & 111 & 91 & 96 \\
\hline
\end{tabular}

a Analyzed by the ferrocyanide method.

\section{TABLE VII}

EFFect of UREA LPON THE STABle (T') AND LABILE (TL) Forms of Tyrosinase FROM NEUROSPORA

The substrate was $7.1 \times 10^{-5} M_{\mathrm{L}-\mathrm{Dopa}}$

\begin{tabular}{|c|c|c|c|c|c|}
\hline \multirow{2}{*}{$\begin{array}{l}\text { Urea con- } \\
\text { centration }\end{array}$} & \multirow{2}{*}{$\begin{array}{l}\text { Minutes } \\
\text { in urea }\end{array}$} & \multicolumn{2}{|c|}{$\Delta$ opt. dens. $\times 10^{3}$} & \multicolumn{2}{|c|}{$\begin{array}{l}\text { Per cent control } \\
\text { velocity }\end{array}$} \\
\hline & & $T^{S}$ & $\mathrm{~T}^{\mathrm{L}}$ & $\mathrm{T}^{\mathrm{s}}$ & $T^{L}$ \\
\hline$M$ & & & & & \\
\hline 0 & - & 150 & 116 & 100 & 100 \\
\hline 8 & $0^{\prime z}$ & 123 & 92 & 82 & 79 \\
\hline 12 & $0^{a}$ & 82 & 63 & 54 & 54 \\
\hline 14.4 & $0^{a}$ & 45 & 33 & 30 & 29 \\
\hline 0 & $5^{b}$ & $137^{\circ}$ & $99^{c}$ & 100 & 100 \\
\hline 12 & 5 & 60 & 38 & 48 & 38 \\
\hline 0 & $15^{b}$ & 114 & 65 & 100 & 100 \\
\hline 12 & 15 & 66 & 19 & 58 & 29 \\
\hline 14.4 & 15 & 21 & 6 & 18 & 9 \\
\hline
\end{tabular}

${ }^{a}$ The assay was carried out immediately after the addition of urea.

${ }^{b}$ Incubation for the appropriate time in the absence of urea.

${ }^{c}$ Figures derived by interpolation.

the assay was narried out as before. Table VII discloses that urea affects the two forms of tyrosinase differentially in that the thermolabile form is more easily inactivaled than is the thermostable one. Essentially the same results were obtained when formamide was used in the same way as urea, as the data in Table VIII reveal. In the case of both substances the difference in the response of the two enzymes did not appear until after an incubation period of at least 5 min., even though inhibition was observable immediately. The inactivation of both enzymes that occurred on standing, in the absence of urea or formamide, has been observed with purified enzymes by others ${ }^{3}$ and appears to be characteristic of tyrosinase from Neurospora.

\section{DISCUSSION}

The enzymic capacities of the two forms of tyrosinase which have been studied appear not to differ significantly, insofar as their substrate specificities, $K_{S}$ values, response to inhibitors, and $\mathrm{pH}$ optima arc 


\section{TABLE VIII}

Effect of Formamide upon the Activity of The Stable ( $T^{\mathrm{S}}$ ) and Labile $\left(\mathrm{T}^{\mathrm{L}}\right.$ ) Forms of TyROSINASE FROM NECROSPORA

The substrate used was $7.1 \times 10^{-5} M_{\mathrm{L}-D o p a}$

\begin{tabular}{c|l|r|r|r|r}
\hline $\begin{array}{c}\text { Formamide } \\
\text { concentration }\end{array}$ & $\begin{array}{c}\text { Minutes in } \\
\text { formamide }\end{array}$ & \multicolumn{2}{|c|}{\begin{tabular}{|}
$\Delta$ opt. dens. $\times$ \\
$10^{3}$
\end{tabular}} & \multicolumn{2}{|c|}{$\begin{array}{c}\text { Per cent control } \\
\text { velocity }\end{array}$} \\
\hline & & $\mathrm{T}^{\mathrm{S}}$ & $\mathrm{T}^{\mathrm{I}}$ & $\mathrm{T}^{\mathrm{s}}$ & $\mathrm{T}^{\mathrm{L}}$ \\
\hline$M$ & & & & & \\
0 & - & 143 & 103 & 100 & 100 \\
$3.6 \times 10^{-1}$ & $0^{a}$ & 114 & 79 & 80 & 77 \\
0 & $5^{b}$ & 130 & 86 & 100 & 100 \\
$3.6 \times 10^{-1}$ & 5 & 70 & 48 & 54 & 56 \\
1.0 & $0^{a}$ & 77 & 60 & 54 & 59 \\
1.0 & 5 & 69 & 37 & 53 & 44 \\
1.8 & $0^{a}$ & 61 & 46 & 43 & 45 \\
1.8 & 5 & 53 & 25 & 41 & 29 \\
3.2 & $0^{a}$ & 40 & 28 & 28 & 27 \\
3.2 & 5 & 31 & 10 & 24 & 12 \\
\hline
\end{tabular}

a The assay was carried out immediately after the addition of formamide.

${ }^{b}$ Ineubated for $5 \mathrm{~min}$. in absence of formamide.

concerned. These observations extend the work begun by Horowitz and Fling (9) and confirm their conclusion that "functionally, the two enzymes are indistinguishable" (7).

That there may be differences which affect secondary and tertiary structure is borne out by the experiments in which the unfolding agents urea and formamide were used. These substances have a consistently greater inhibitory effect on the thermolabile form of the enzyme ( $\mathrm{T}^{\mathrm{L}}$ ) than upon the stable one $\left(T^{\mathrm{s}}\right)$. This difference, along with those in thermal tolerance and electrophoretic mobility, points in the direction of a structural modification which alters the number and/or kind of bonds to which the folding characteristic of proteins is attributable.

The substrate specificity of Neurospora tyrosinase is roughly parallel to that of polyphenolases described from other organisms. However, there are differences in the relative effectiveness of the substrates. Thus, although Dopa is a better substrate for mushroom and Neurospora tyrosinase than is chlorogenic acid, the latter is the best substrate for the sweet potato enzyme (4). Catechol is oxidized about as rapidly as Dopa by the Neurospora enzyme, but reaction-inactivation is extremely rapid, making accurate determinations of rate very difficult. This explains why manometric techniques (15) failed to reveal the activity of Neurospora tyrosinase on catechol because measurements must be made within the first minute after the reaction is initiated and low concentrations of substrate must be used. Phenyl-4-catechol is the best substrate of those tried and appears to be used by other fungal tyrosinases as well (18).

Although the conclusions based upon the comparison of the activity of the two forms of tyrosinase are not affected by the reliability of the measurements with the ascorbate technique, the absolute rates and the $K_{S}$ values are. The tests outlined in the section on Methods revealed that the method is reliable for use with diphenols, in agreement with other workers who have found that ascorbate has no effect upon the oxidation of these substrates by tyrosinase (11, $17,19)$. However, the significance of the rates of oxidation of monophenols is not at all certain. Thus, it has been found that ascorbate increases the rate of oxidation and disappearance of tyrosine, especially in the early stages of the reaction (12-14). Moreover, part of the oxidation of ascorbate is coupled to the shuttle involving catechol and $o$-quinone, and the fraction of the oxidation due to monophenolase activity remains undetermined. In addition, changes in substrate concentration, as well as in the kind of substrate, may affect the proportion of the oxidation due to monophenolase activity. Therefore, the $K_{S}$ values for the enzyme with tyrosine (Table II) are to be questioned, as are the absolute rates for the oxidation of monophenols listed in Table III. However, it is worth noting that no technique yet evolved provides unequivocal values for the oxidation of monophenols. The meaning of such rates is obscured by the oxidation of diphenols which is a concomitant of the initiation of the reaction. In fact, it has been suggested (14) that "In the absence of reducing agents, maximum activation is not obtained and ... true phenolase activities can only be found in the 
presence of reducing agents." In any event, the conclusion that the enzymes from $T^{\mathrm{s}}$ and $\mathrm{T}^{\mathrm{L}}$ do not differ in their response to the substrates tried appears to be warranted, whether or not the absolute rates for the oxidation of monophenols are reliable.

As was mentioned in the section on Meth$o d s$, the lag period in the oxidation of tyrosine is present when either the crude or purified enzyme is used in the ascorbate system. On the other hand, it has been shown ${ }^{3}$ that when the oxidation of this substrate by purified enzyme systems is studied directly by the accumulation of halochrome, the lag period is eliminated. Furthermore, these results differ from those of others $(3,13,14)$ in that the lag period has been reported to be removed by reducing agents like ascorbate. The resolution of these contradictions must await clarification of the nature of the lag period itself.

\section{ACKNOWLEDGMENTS}

I wish to thank Dr. Norman H. Horowitz for making the facilities of his laboratory available to me. In addition, I wish to acknowledge the considerable help and encouragement provided by Dr. Horowitz, Dr. Marguerite Fling, Miss Helen Macleod, and the staff of the Biological Division of the California Institute of Technology. Finally, Mr. Wendell Ing assisted in the performance of several experiments and aided in many of the computations.

\section{REFERENCES}

1. Bald, E., J. Biol. Chem. 118, 219 (1937).

2. El-Bayoumi, M. A., and Frieden, E., J. Am. Chem. Soc. 79, 4854 (1957).

3. Beh., R. C., ANd Nelson, J. M., J. Am. Chem. Soc. 66, 711 (1944).
4. Eiger, I., axu Dawson, C. R., Arch. Biochem. Biophys. 21, 194 (1949).

5. Graubard, M., and Nelson, J. M., J. Biol. Chem. 111, 757 (1935).

6. Horowitz, N. H., ANd Flisg, M., Genetics 38, $360(1953)$.

7. Horowitz, N. H., and Fling, M., in "Enzymes: Units of Biological Structure and Function" (O. H. Gacbler, ed.), p. 139. Academic Press, New York, 1956.

8. Honowitz, X. H., Flivg, M., Macleod, H. L., A.n Sueoka, N, J. Mol. Biol. 2, 96 (1960).

9. Horowitz, N. H., Flivg, M., Macleod, H. L., AND Sueoka, N., Genetics 46, 1015 (1961).

10. Horowitz, N. H., and Shex, S.C., J. Biol. Chem. 197, 513 (1952).

11. Ingramin, L. L., J. Am. Chem. Soc. 78, 5095 (1956).

12. Kindal, I. P., Biochem. J. 44, 442 (1949).

13. Kruegir, R. C., J. Am. Chem. Soc. 72, 5582 (1950).

14. Kruegri, R. C., Arch. Biochem. Biophys. 76, 87 (1958).

15. Kuwana, H., Ann. Rept. Sci. Works, Fac. Sci., Osaka Univ. 4, 117 (1956).

16. Lowry, O. H., Rosebrough, N. J., Farr, A. L., and Randall, R. J., J. Biol. Chem. 193, 265 (1951).

17. Miller, W. H., axj Dawson, C. R., J. Am. Chem. Soc. 64, 2344 (1942).

18. Rich, S., and Horsfald, J. G., Proc. Natl Acad. Sci. U. S. 40, 139 (1954).

19. Scharf, W.. and Dawson, C. R., J. Am. Chem. Soc, 80, 4627 (1958).

20. Sistek, F. C., and Evans, H. J., Plant Phsysiol. 33, 255 (1958).

21. Vociri, H. J., Microbiol. Genetics Bull. 13, 42 (1956).

22. Waugh, D. F., Advances in Protein Chem. 9, 325 (1954).

23. Yasunobt, K. T., and Yorris, E. R., J. Biol. Chem. 227, 473 (1957). 